\title{
Clinical Outcomes of Post Renal Transplant Patients with COVID-19 Infection: A single-center case series
}

Shaikh Maheboob ${ }^{1}$, Mohamad Khatib ${ }^{1}$, Mohammad Alwraidat ${ }^{1}$, Dore Ananthegowda ${ }^{1}$, Muftah Abdallah $^{1}$, Asra Aroos ${ }^{1}$, Sagar Jujjavarapu ${ }^{1}$, Saptarshi Banerjee ${ }^{1}$, Zishan Nasir ${ }^{1}$, Ahmed soliman Mohamed ${ }^{1}$, Moustafa Elshafei ${ }^{1}$, and Abdulqadir Nashwan ${ }^{1}$

${ }^{1}$ Hamad Medical Corporation

March 15, 2021

\begin{abstract}
Post renal transplant patients are generally immunosuppressed and remain at a higher risk for getting bacterial and viral infections. Most of these patients are taking immunosuppressive medications, including steroids. This case series highlights the clinical outcomes and characteristics of 8 post renal transplant patients who acquired COVID-19.
\end{abstract}

\section{Clinical Outcomes of Post Renal Transplant Patients with COVID-19 Infection: A single-center case series}

Short title: Post Renal Transplant and COVID-19

Shaikh N. Maheboob ${ }^{1}$, Mohamad Y. Khatib ${ }^{2}$, Mohammad A. Al Wraidat ${ }^{2}$, Dore C. Ananthegowda ${ }^{2}$, Muftah A. Abdallah ${ }^{3}$, Asra Aroos ${ }^{2}$, Sagar B. Jujjavarapu ${ }^{3}$, Saptarshi Banerjee ${ }^{2}$, Zishan Nasir ${ }^{3}$, Ahmed S. Mohamed ${ }^{2}$, Moustafa S. Elshafei ${ }^{2}$, Abdulqadir J. Nashwan ${ }^{2}$

1. Surgical Intensive Care Department, Hamad General Hospital (HGH), Hamad Medical Corporation (HMC), Doha, Qatar.

2. Medical Intensive Care Department, Hazm Mebaireek General Hospital (HMGH), Hamad Medical Corporation (HMC), Doha, Qatar.

3. Nephrology Department, Hazm Mebaireek General Hospital (HMGH), Hamad Medical Corporation (HMC), Doha, Qatar

Corresponding author:

Mr. Abdulqadir J. Nashwan

anashwan@hamad.qa

Tel: $(+974) 40240487$

Mob: (+974) 66473549

P.O.Box 3050 Doha, Qatar

\section{Abstract}

Post renal transplant patients are generally immunosuppressed and remain at a higher risk for getting bacterial and viral infections. Most of these patients are taking immunosuppressive medications, including steroids. This case series highlights the clinical outcomes and characteristics of 8 post renal transplant patients who acquired COVID-19. 
Keywords: COVID-19 infection, hypertension, acute kidney injury, immunosuppression, renal transplant, end-stage renal disease

\section{Key Clinical Message:}

There is a paucity of available literature regarding the impact of COVID-19 infection in post-renal transplant patients. These patients have a higher chance of acquiring severe COVID-19 infection, more complications, and poor prognosis.

\section{Background}

Coronavirus disease (COVID-19) started in China as a severe pneumonia of unknown cause in late 2019 and quickly spread throughout the world with human-to-human transmission. COVID-19 was declared a pandemic in the first quarter of 2020 by the World Health Organization (WHO) and has caused a significant loss of human lives and financial resources worldwide.(1) The pandemic is far from being over and has compromised even the most developed countries' healthcare systems. There are various risk factors for getting severe COVID-19 infection, such as patients' age, co-morbidities such as diabetes, cardiovascular and chronic respiratory disorders (2-4). However, the role of immunosuppression therapy is still not clear.(5) Use of the immunosuppressant medication in post-renal transplant patients may increase the risk of various viral infections.(6)

Adequate literature is not available from the region regarding the impact of COVID-19 infection in post-renal transplant patients, whereas the international literature is limited to a case series with contrast findings and conclusions.(7)

This case series explores the occurrence of COVID-19 infection in post-renal transplant patients, their risk factors, severity, course of the disease, and outcomes.

\section{Patient and Methods}

We enrolled all post renal transplant patients diagnosed with COVID-19 infection with a Polymerase chain reaction test (PCR) who were admitted to the intensive care unit (ICU) of our hospital from $1^{\text {st }}$ March to $30^{\text {th }}$ September 2020. All patient's demographic data, number and type of comorbidities, type and timing of the transplant, current patient medications, the severity of the disease, sepsis markers, acute kidney injury, renal replacement therapy requirements, secondary infections, ventilatory requirements, and ventilator days, need of vasopressors and outcomes were recorded retrospectively from the patients' electronic data files.

\section{Results}

A total of 8 post renal transplant patients with COVID-19 were admitted to our intensive care unit during the study period. Five of the eight patients were female. The most common comorbid condition among all our patients was hypertension (all 8 patients). Four of our patients were type-II diabetic. Another 4 patients had a previous history of respiratory disease (chronic), including asthma or chronic obstructive pulmonary disease (COPD), while coronary artery disease and hyperlipidemia was present in 4 and 1 patient, respectively (Table 1). Five patients had a history of a renal transplant from living related donors, while 3 patients had received their kidneys from cadaveric donors. Post renal transplant period ranged from 4 to 16 years with a mean of 8.6 years (Table 2). Septic markers, including COVID-19 severity markers, were significantly elevated (c-reactive protein, ferritin, d-Dimer, and fibrinogen). Mean APACHE score as 13.88 with a range of 6-20 (Table 2). All patients had been taking immunosuppressant medications and steroids at the time of infection with the virus. Secondary bacterial infection occurred in 3 patients, 3 patients required invasive ventilatory support, and 3 patients received renal replacement therapy, including hemodialysis, after developing acute kidney injury (Table 3). Mean mechanical ventilation days in the 3 intubated patients were 20.19 with a range of 14 to 25 days (Table 3). Four patients required vasopressors to maintain their hemodynamics. One patient died while staying in the ICU giving a mortality of $12.5 \%$ in our patient series. (Table 3 )

\section{Discussion}


Post renal transplant patients are hypothetically at a higher risk of acquiring COVID-19 infection due to various reasons, including immunosuppressive medication, steroid therapy, and malnutrition.(6) Elias et al identified obesity, diabetes mellitus, and chronic pulmonary diseases as some of the risk factors in post-renal transplant patients for getting COVID-19 infection.(8) Elhadedy et al. also found that hypertension and Diabetes mellitus were the most common risk factors for COVID-19 infection in this group of patients.(9) The most common risk factors or comorbidity were hypertension, Diabetes mellitus, and chronic pulmonary disease in our patient population. All our patients had undergone kidney transplants years back, and most received the kidney from live-related donors. This contrasted with most of the literature, which states that cadaveric renal transplants and recently transplanted renal recipients were at a higher risk of acquiring COVID-19 infection. $(8,9)$ We also had a higher number of female patients, which is in contrast to the available literature. $(8,9)$ Similarities to literature include having very high inflammatory and sepsis markers, including ferritin, $\mathrm{C}$ reactive protein, fibrinogen, and D Dimers. Immunosuppressants medications were continued in lower doses, and our patients also received steroids during their ICU stay. Acute kidney injury and the requirement of renal replacement therapy is also common with COVID-19 infection. A study from England reported that 57\% of post renal transplant patients with COVID-19 required renal replacement therapy.(10) Elhadedy et al reported that $26 \%$ of their patients required hemodialysis. Our patient's series $26 \%$ of this group of patients required renal replacement therapy. $37 \%$ of our patients required intubation and invasive ventilation. Elias et al reported that $22 \%$ of their patients required invasive ventilation.(8) Banerji et al reported one (14\%) out of their 7 patients required invasive ventilation.(10) Available literature describes that post renal transplant patients with COVID-19 infection had higher mortality than the general population, ranging from 14 to $24 \%$. $(8,10)$ In our case series, mortality was $12.5 \%$ as one of our eight patients died from complications of the disease.

\section{Conclusion:}

Post renal transplant patients have high chances of complications with COVID-19 infection due to their immunosuppressed status and related comorbidities. They also have a significant risk of developing acute kidney injury and severe pneumonia requiring invasive ventilation. In our case series, hypertension was a common risk factor, and female patients were more significant in number. Most of the patients had received the transplanted kidneys years ago, and all of them were taking immunosuppressive medications, including steroids. Complications of disease and mortality among these critical patients were high.

\section{Declarations}

\section{Ethics approval and consent to participate}

The article describes a case series. Therefore, no additional permission from our Ethics Committee was required.

\section{Consent for publication}

The consent for publication was obtained.

\section{Availability of data and material}

All data generated or analyzed during this study are included in this published article.

\section{Competing interests}

The authors declare that they have no competing interests.

\section{Funding}

This study was not funded.

\section{Authors' contributions}

SNM, MYK, MAW, DCA, MAA, AAO, SBJ, SBE, ZNR, ASM, MSE, AJN: Data Collection, Literature Search, Manuscript Preparation. 
All authors read and approved the final manuscript.

\section{Acknowledgments}

Open Access funding provided by the Qatar National Library.

\section{References}

1. Organization WH. Coronavirus disease (COVID-19) Weekly Epidemiological Update and Weekly Operational Update. 2020.

2. Iqbal FM, Soliman, A., De Sanctis, V., Mushtaq, K., Nair, A. P., Al Masalamani, M., Sasi, S., Ali, E., Hassan, O., Nashwan, A. J., Fahad, J., Yassin, M. A. Prevalence, Clinical Manifestations, and Biochemical Data of Hypertensive versus Normotensive Symptomatic Patients with COVID-19: A Comparative Study. Acta Bio Medica Atenei Parmensis. 2020;91(4):e2020164.

3. Soliman AT, Prabhakaran Nair A, Al Masalamani MS, De Sanctis V, Abu Khattab MA, Alsaud AE, et al. Prevalence, clinical manifestations, and biochemical data of type 2 diabetes mellitus versus nondiabetic symptomatic patients with COVID-19: A comparative study. Acta Bio Medica Atenei Parmensis. 2020;91(3):e2020010.

4. Khatib MY, Peediyakkal MZ, Elshafei MS, Elzeer HS, Ananthegowda DC, Shahen MA, et al. Comparison of the clinical outcomes of non-invasive ventilation by helmet vs facemask in patients with acute respiratory distress syndrome. Medicine. 2021;100(4).

5. Etienne N, Karmochkine M, Slama L, Pavie J, Batisse D, Usubillaga R, et al. HIV infection and COVID19: risk factors for severe disease. AIDS (London, England). 2020;34(12):1771.

6. Linares L, Cofán F, Cervera C, Ricart M, Oppenheimer F, Campistol J, et al., editors. Infection-related mortality in a large cohort of renal transplant recipients. Transplantation proceedings; 2007: Elsevier.

7. Mahalingasivam V, Craik A, Tomlinson LA, Ge L, Hou L, Wang Q, et al. A Systematic Review of COVID-19 and Kidney Transplantation. Kidney International Reports. 2020.

8. Elias M, Pievani D, Randoux C, Louis K, Denis B, Delion A, et al. COVID-19 infection in kidney transplant recipients: disease incidence and clinical outcomes. Journal of the American Society of Nephrology. 2020;31(10):2413-23.

9. Elhadedy MA, Marie Y, Halawa A. COVID-19 in Renal Transplant Recipients: Case Series and a Brief Review of Current Evidence. Nephron. 2020:1-7.

10. Banerjee D, Popoola J, Shah S, Ster IC, Quan V, Phanish M. COVID-19 infection in kidney transplant recipients. Kidney international. 2020;97(6):1076-82.

Table 1: Patients demography and comorbidities

\begin{tabular}{lllllll}
\hline Patient & Gender & Age (Years) & Diabetes mellitus & Hypertension & Coronary Artery Disease & Chronic Respi \\
\hline 1 & Female & 61 & No & No & No & Yes \\
2 & Female & 35 & No & Yes & No & No \\
3 & Female & 53 & No & Yes & No & Yes \\
4 & Male & 54 & Yes & Yes & No & No \\
5 & Male & 63 & Yes & Yes & Yes & YES \\
6 & Female & 61 & YES & YES & NO & NO \\
7 & Male & 55 & NO & YES & YO & YES \\
8 & Female & 51 & YES & YES & YES & Yes: $4(50 \%)$ \\
& 5: Female/3: Male & Mean $=54.1$ & Yes:4(50\%) & Yes: $7(87.5 \%)$ & Yes:2 $(25 \%)$ & \\
\hline
\end{tabular}


Table2: Renal transplant detail and markers

\begin{tabular}{|c|c|c|c|c|c|c|c|}
\hline $\begin{array}{l}\text { Patient } \\
\text { Number }\end{array}$ & $\begin{array}{l}\text { Years of } \\
\text { transplant }\end{array}$ & $\begin{array}{l}\text { Type of } \\
\text { renal } \\
\text { transplant }\end{array}$ & $\begin{array}{l}\text { APACHE2 } \\
\text { Score }\end{array}$ & $\begin{array}{l}\text { Ferritin } \\
\text { levels }\end{array}$ & d-Dimer & Fibrinogen & $\begin{array}{l}\text { C-reactive } \\
\text { protein }\end{array}$ \\
\hline 1 & 4 & $\begin{array}{l}\text { Live } \\
\text { related } \\
\text { Donor }\end{array}$ & 8 & 587 & 0.85 & 4.8 & 165.4 \\
\hline 2 & 11 & $\begin{array}{l}\text { Deceased } \\
\text { donor }\end{array}$ & 12 & 367 & 0.81 & 3.6 & 30 \\
\hline 3 & 5 & $\begin{array}{l}\text { Live } \\
\text { related } \\
\text { Donor }\end{array}$ & 6 & 693 & 1.77 & 8.2 & 287.6 \\
\hline 4 & 5 & $\begin{array}{l}\text { Deceased } \\
\text { donor }\end{array}$ & 11 & 1398 & 0.55 & 4.3 & 76.6 \\
\hline 5 & 6 & $\begin{array}{l}\text { Deceased } \\
\text { donor }\end{array}$ & 25 & 335 & $\mathrm{~N}$ & 5 & 295.5 \\
\hline 6 & 9 & $\begin{array}{l}\text { Live } \\
\text { related } \\
\text { Donor }\end{array}$ & 15 & 1010 & 0.91 & 4.8 & 42 \\
\hline 7 & 16 & $\begin{array}{l}\text { Live } \\
\text { related } \\
\text { Donor }\end{array}$ & 14 & 386.00 & 1.03 & 4.8 & 156.7 \\
\hline \multirow[t]{2}{*}{8} & 13 & $\begin{array}{l}\text { Live } \\
\text { related } \\
\text { Donor }\end{array}$ & 20 & 1467 & 1.07 & 5 & 104.4 \\
\hline & Mean=8.6 & $\begin{array}{l}\text { Live related } \\
\text { Donor }=5 \\
\text { Deceased } \\
\text { donor }=3\end{array}$ & Mean:13.88 & Elevated & Elevated & Elevated & Elevated \\
\hline
\end{tabular}

Table3: Descriptive and outcome parameters

\begin{tabular}{|c|c|c|c|c|c|c|}
\hline $\begin{array}{l}\text { Patient } \\
\text { Number }\end{array}$ & $\begin{array}{l}\text { Acute } \\
\text { kidney } \\
\text { injury (AKI) } \\
\text { required } \\
\text { RRT }\end{array}$ & $\begin{array}{l}\text { Secondary } \\
\text { infection }\end{array}$ & Intubation & $\begin{array}{l}\text { Mechanical } \\
\text { Ventilation } \\
\text { days }\end{array}$ & $\begin{array}{l}\text { Total ICU } \\
\text { stay (days) }\end{array}$ & Mortality \\
\hline 1 & No & Yes & Yes & 14 & 20 & No \\
\hline 2 & No & No & No & 0 & 2 & No \\
\hline 3 & Yes & Yes & Yes & 24 & 25 & Yes \\
\hline 4 & Yes & Yes & Yes & 25 & 64 & No \\
\hline 5 & No & Yes & No & 0 & 19 & No \\
\hline 6 & No & No & No & 0 & 3 & No \\
\hline 7 & No & No & No & 0 & 8 & No \\
\hline \multirow[t]{3}{*}{8} & YES & YES & $\mathrm{NO}$ & 0 & 41 & $\mathrm{NO}$ \\
\hline & Required & Yes:5(62.5\%) & Yes:3(37.5\%) & Mean:20.19 & Mean:22.75 & Yes:1(12.5\%) \\
\hline & RRT: $3(37.5 \%)$ & No:3(37.5) & No:5(62.5\%) & & & \\
\hline
\end{tabular}

